\title{
The Poetics of Crisis: Poets in Dialogue
}

\author{
Jamie K. Reaser ${ }^{1,2,3}$ (D) J. Drew Lanham ${ }^{4} \cdot$ Theodore Richards $^{5}$
}

Received: 22 July 2020 / Revised: 7 September 2020 / Accepted: 1 October 2020 /

Published online: 6 November 2020

(c) Springer Nature Switzerland AG 2020

\begin{abstract}
As part of the American University in Paris' 2020 Conference on the Psychology of Global Crises, we collaborated in a panel discussion entitled the Poetics of Crisis in which we explored the role of poetry as a medium of personal and transpersonal expression during times of crisis, as well as a means for transmuting crisis into an opportunity, a platform, for generative change. Here, we continue the dialogue, three award-winning poets exploring how words - through our own approach to literary writing - can invoke human potential during challenging times. We reflect on poetry in form, as an offering to and conveyance of beauty amidst pain, as protest in the way that it can demarcate what no longer serves sentiment and survival, and as a spark of revolution-the inspiration and guide when the necessary changes are called out and called up for the sake of humanity. We conclude with a poetic invitation.
\end{abstract}

Keywords Crisis $\cdot$ Poetry $\cdot$ Conversation $\cdot$ Beauty $\cdot$ Revolution

\section{Introduction}

"Poetry offers psychology its own perspective on the reaches of the realm, a unique repository not only of energy, but also of imagery, metaphor, paradox, inversion, contradiction, and often enough beauty. Poetry valorizes and embraces the resources of the unconscious." (Akhter, 2013).

Prominent psychologists have unabashedly, and with great reverence, recognized poetry as portal into the subconscious. Carl Jung, for example, notes that "the poet who responds to the prompting of the unconscious is able to tap deep emotional sources" (Jung, 2015). In this light, he may have regarded poets as a type of well-travelled depth

\section{Jamie K. Reaser}

jamiekreaser@gmail.com

1 Giving Voice to Resilience LLC, VA, Stanardsville, USA

2 Department of Environmental Science and Policy, George Mason University, Fairfax, VA, USA

3 Department of Natural Resources, University of Rhode Island, RI, Providence, USA

4 Department of Forestry and Environmental Conservation, Clemson University, SC, Clemson, USA

5 Chicago Wisdom Project, Chicago, IL, USA 
psychologist-aeronauts of the underworld. Robert Romanyshyn (2007) acknowledges poetry as an expression, an art, of the soul. He regards psychologists, seemingly with a sense of exasperation, as "failed poets" for a lack of ability to fully bridge the gap between the conscious and unconscious minds, as is the natural aptitude of poets. His overarching message seems to be that an inability to bridge this gap limits the psychologist's ability to discern the key momentary truths, and thus, he urges modern psychologists to "keep the soul in mind" in order to hone their aptitudes for sensibility towards that of a poet. Wachs (2011) explores psychology's need for poetry, concluding that poetry is a means by which a person can become sensible through the discovery of purpose, finding the meaningfulness in and of their lives. Writing and reading poetry is, therefore, a process by which one can literally and figuratively come to their senses-in psychological terms, achieve mental health.

What, then, is the psychologically-transformative potential of poetry when it seems the world has gone mad? In what way can poetry be an ally of the psyche and the psychologist when the collective unconscious casts its thick, broad shadow across the societal landscape? In what way can poetry light the way for revolution, a turnaround-perhaps the necessary psychotic break-through which the human species can face its self in the chaotic darkness of separation from our shared humanity?

On May 25, 2020, as part of the American University in Paris' Conference on the Psychology of Global Crises, we collaborated in a panel discussion entitled, the Poetics of Crisis in which we explored how crisis gives voice and purpose to poetry and how poetry gives voice and purpose to crisis. Each of us spoke to the theme from personal and transpersonal perspectives influenced by our shared interests in nature and human nature. We read crisisthemed poems from our own award-winning literary publications, responded to participate questions, and concluded by jointly reciting Rainer Maria Rilke's poem, I Am Much Too Alone in This World, Yet Not Alone (https://www.youtube.com/watch?v=mq3vLzOm5Hc; accessed 9 July 2020).

At the time of the event, the entire world was experiencing the early stages of severe acute respiratory syndrome coronavirus 2 (SARS-CoV-2; the agent of COVID-19 disease), a pandemic driven by the combined forces of habitat destruction, land use change, and globalization of the trade, travel, and transport sectors.

"All around the world, — we the entire human species — are now encaved in our homes. Isolation, loneliness and, for some, forced fasting invoke a dark night of the soul. Death is dancing in front of billions of witnesses." (Reaser, 2020).

On the same day - at the same time - of our presentation, racism was a darkness creeping across New York City's Central Park, at the margins of bird-enlivened shrubby undergrowth, and also on an asphalt street of Minneapolis, MN, where eight minutes demonstrated that humanity has not spent enough time seeking itself out among the brambles that grow at the psyche's margins, where we decide what of the soul lives and dies underneath our individual and collective skin.

"I thought my color would cost me my life...I'm not alone, though. I have friendsblack friends-who've also experienced the lingering looks, the stares of distaste. They've endured comments about their color flung within earshot. I look at maps through this lens - at the places where tolerance seems to thrive, and where hate and racism seem to fester-and think about where I want to be." (Lanham 2016).

What could we, purveyors of lyrically inclined small words and phrases, offer to the masses in a time of thickening, global-scale crises? Just that: the profound, readily 
accessible beauty that exists in the simplicity of being - calling, guiding, and uniting wherever there is courage enough to exalt the sky with dawn-invoking voices. Continuing the conversation that we began as panelists, we have offered further reflection on the poetics of crisis in a Reimaging Magazine collaboration (reimaginingmagazine.com). Here, in the special issue of Human Arenas associated with the Psychology of Global Crisis 2020 conference, we enter into dialogue again, exploring poetry's role in protest, acceptance, and revolution.

\section{In Dialogue}

Q/JKR: Crisis exists at the interface of dissolution and emergence. Stéphane Mallarmé, a nineteenth century French poet, wrote that "poetry is the language of a state of crisis" (Mallarmé et al. 2006). In your own experience how this is true, and how is this truth reflected in your own poetry?

A/TH: On a very personal level, I can say that much of my own poetry has arisen out of crisis, whether it be personal or global. Poetry is beauty, of course, but I think some pain is required, too. Most of the work of the poet isn't writing; it's loving the world enough to suffer with it. Loving the world enough, feeling its depth and subjectivity, inevitably involves experiencing its pain.

A/JDL: I see poetry as the art of the immediate. These plagues - yes, plagues -of nature, politics, and bias, are immediately abundant targets for poetic reflection and introspection. For me, it is all a flash flood rising overland. The struggle is to not be overcome. And so, I write to the moment more than any memory of it. I write to feel the raw of the instant-whether joy of some beauty or despair of some pain-so that what I felt is felt. There is something lost beyond that instant. My poetry is mostly plein air in that I want it soaked in what I see or hear or smell or touch or otherwise sense in being in the midst of whatever is happening. I always feel that the editing process dulls the sharpness if one isn't careful in the post-processing. I believe poetry to be the tool of the immediate and so, now as much as any before, the world demands our work reflect the now.

Q/JKR: In his essay, I Thought You Were a Poet, Joshua Mehigan (2011) explores the link between poetry and psychological distress, noting that when King Lear is mad, he speaks prose. All of us have published works in prosaic and poetic form. We've written books and articles from the persona of scientists, teachers, and cultural change agents. Our "pens" have options. Why and how can poetry attend to crisis, to an unmaddening of the crowd, in a way that prose cannot?

A/TH: On some level, crisis involves a collapsing of self and identity that simply cannot be articulated in prose. If prose can explain things as they are, poetry can reimagine them, can offer possibilities for what might be. The poet can bring forth what might even seem impossible.

A/JDL: Poetry is an act of emotional efficiency in many ways. I like to think of it as extended haiku. How best to say what's felt in fewest words-or the best words. Poetry is a practice that demands constant work. I don't believe that any poem is ever "finished" as one might conclude an essay. A poem concludes for the moment of feeling; there is nothing left to say beyond the moment. The flower is the flower in that moment. The new that has visited it just moments before or the butterfly that may come after our seeing it, is not necessarily the concern of the poem. That challenge of immediacy prevails in my poetics. 
I think it's crucial in these times that we show our current states of being, painful as they are.

Q/TH: We are confronted with myriad crises, inter-connected through the symbols and stories of capitalist civilization. We need new language, language that reflects a more holistic, ecological, organic worldview. How do you see the transformation of language in the world that is emerging through the crisis of climate, health, and social justice movements? What are the ways we communicate now that interfere with our fully embracing the changes that are emerging?

A/JDL: We talk past one another to crowds of emoticons and "likes" that do not allow us to be intimate in our dealings. We are crowd sourcing words and in some ways that is an immensely powerful and useful lever. In other ways, though, it dulls us. We know one another by avatar more than true face, and so we become numb in conversations driven more by algorithm than shared interest.

A/JKR: In the context of our current societal crises and their associated movements, I have been giving considerable thought to the words resistance and resilience. From my perspective, to resist is to set boundaries. It is to say, "No!" to a potential violation. To resist provides an opportunity for a pause, perhaps a stop, to a process-a flow of energy. Resistance can hold space for transformation to occur, but it is not in and of itself the act of transformation. Resilience permits the enactment of a process, a force, but also the recovery from it. Resilience is more of a creative force than resistance, but it is not explicitly generative-the word speaks to a return to a pre-existing condition, but not growth, not expansiveness. I'm searching for the third word, a word that explicitly leads us through a transformative process into a state of being and behaving that is more unifying than polarizing, more uplifting than degrading, more generatively witnessing than shaming, more sustainable than depleting. I want the word the phoenix calls out when it takes flight.

Q/JDL: At what point does your poetry become protest? What's the intent of your words - to assuage or incite?

A/TH: In a sense, all poetry is protest. For it rales against the tendency to reduce our world to the prosaic, the tyranny of the quantifiable. Poetry affirms that there are ways of knowing that aren't reducible to the rational and logical mind. Moreover, it affirms that we can find joy and beauty in the midst of the struggle.

A/JKR: I think poetry is always in protest of what is hidden, untrue, and divisive. Poetry is a call to attentiveness-externally and internally. It is also a conveyance by which we can reach an understanding of the personal as transpersonal and visa-versa; poetry unveils and calls forth relatedness. In this regard, poetry is a protest against deliberate attempts to use words to conceal, falsify, divide, and isolate in order to instigate and maintain injustices. My writing explores the interface of Nature and human nature, always through the voice of a truthsayer-sometimes human, sometimes other-than-human. A truthsayer's toolkit needs to include words that assuage, as well as words that incite. In some contexts, particularly those that are crisis-driven, the same word may play both roles-motivating some people toward a platform or issue and others away from it. At this time in U.S. history, this includes words associated with our sense of national identity: patriot, citizen, native, alien, immigrant, and colonist to name a few.

Q/JDL: What's the rationale for writing to beauty in a time of pain, of crisis?

A/TH: This is the greatest of all protests, isn't it? "To fall in love with the world," as Derek Walcott says, "in spite of history” (Wallcott 1992). I would suggest that one of the purposes of fascism is to breed nihilism and cynicism. Justice and joy must come together for a true revolution to take place; for the opposite of the cynicism of fascism isn't leftist politics-although that helps-but poetry. 
A/JKR: Our sense of aesthetics - the depth and breadth of our aesthetic values-influences and is influenced by our belief systems. In turn, these values influence our actions, including our relationships with self and other. Those with a wide range of aesthetic value are inherently more attentive to nuance-diversity and difference-but are also more inclusive. They may be more inclined to seek understanding in painful situations because they recognize understanding as a process by which cosmologies can be further expanded, unveiling even more beauty. The recognition of beauty during crisis is a bold act of association and attentiveness. Beauty is what can anoint a wound, making it sacred. That is the alchemy of healing for a deeply wounded person, place, or People. Thus, writing to beauty in a time of pain is an active prayer for understanding, acceptance, and solidarity through beingness - the relatedness of all life. This is our collective "be" longing.

Q/TH: Revolution requires new language. Our words reflect and create the worldview that defines us. It is through our worlds that we come to understand power relationships and where we each fit in. So, while changing the political or legal realities is important, we often get trapped in the same cycles if we cannot change our language-our way of seeing the world. In what way(s) do words and the way we use them matter in a fight against injustice?

A/JDL: I believe that now must hold fast to the true democracy of the words we use. We cannot censor or censure ideas lest we censor ourselves down the line. Say what you mean and write that. Now is not the time for mollycoddling the language. We must be careful in how we wield the power of words, but we must also use the power to great and good effect. I don't believe in word or phrase ownership. However, we must always bear in mind the barter between words and meaning - whether perceived or real. A term of endearment for some that is the horrific racist slander when used by others, cannot be punctuated out in half spelling. It still bears power in the hieroglyphs.

A/JKR: Words are energetic imprints that we construct and respond to. They are a currency of relationship, having the ability to deplete or strengthen human bonds. Beliefs about the meaning of words give words their action potential — to polarize or unify. Despite the existence of dictionaries, word meanings are dynamic-they change over time and with context. Human conflict is frequently a war of words driven by different projections of meaning onto a series of letters-with each person presuming their projected meaning is, or should be, fixed and universal. Word meanings are perceived to have value and that value is interpreted emotionally. Word use violations, as judged by individuals or society, are thus experienced as a violation of values - and core values are generally regarded as something worth fighting for, a just cause. We have an ethical responsibility for word choice, as well as to do our best to understand another narrator's choice of words.

\section{Conclusion}

"If we are to once again experience the cosmos as our womb, to participate meaningfully in the awesome event called the universe, then we must simply work outside, pause, and look at the shining stars, or see a child being born, or listen to a tree's leaves rustling in the wind, and be amazed." (Richards 2011).

Every act of birthing involves crisis. Coming again into the world is an opportunity to see with new eyes, listen with new ears, to feel-differently and universally. What we need now is to recognize that this birthing is not an act of separation from our most nourishing source but a cry for unification that requires the human soul to take form. 
We conclude with an offering, a simple yet profound invitation to lift your own pen and vulnerably courageous voice:

Come alive, now, in this morbidly rich writing environment. Wade into the midst of the pain and despair to tell the truth, letting others know the depth of it and how easy it is to become stuck. Write to the immediate, fearlessly. Give the words permission to cut as close to the edge, to whatever moved you to sense the very first word or craft the enduring phrase- the one that won't let go of you, that provides lift. Write to the beauty that triumphs its way up out of the mire-somehow, always.

In the practice of poetics, persistence is hope. It is what gives words the synonymy of freedom and home. May we-as individuals and a species-come to our senses in the midst of crisis and, in doing so, discover that the leaves we hear rustling adorn the tree of all life. May we be amazed by its beauty?

Acknowledgments Many thanks to Irene Strasser for the invitation to contribute to this special issue and her supportive guidance throughout the publication process. The manuscript was improved through the invocation of two anonymous reviewers.

\section{Compliance with Ethical Standards}

Conflict of Interest The authors declare that they have no conflict of interest.

\section{References}

Akhter, T. (2013). Relation between poetry and psychology with special reference in the poetry of Kamala Das. IOSR Journal of Humanities and Social Sciences, 9, 13-16.

Jung, C. G. (2015). The theory of psychoanalysis: Scholar's (choice). Sheridan, Wyoming: Creative Media Partners LLC.

Lanham, J. D. (2016). Birding while black. Literary Hub September 22, 2016. https://lithub.com/birdingwhile-black/. Accessed 31 August 2020.

Mallarmé, S., Blackmore, E. H., \& Blackmore, A. H. (2006). Collected poems and other verses. Oxford, UK: Oxford University Press.

Mehigan, J. (2011). I thought you were a poet: a notebook. Poetry Magazine April 11, 2011. https://www. poetryfoundation.org/poetrymagazine/articles/69713/i-thought-you-were-a-poet. Accessed 31 August 2020.

Reaser J. K. (2020). Bat medicine: dosage for a modern pandemic. Medium March 29, 2020. https://mediu m.com/@jamiekreaser/bat-medicine-dosage-for-a-modern-pandemic-168ede42ad83. Accessed 31 August 2020.

Richards, T. (2011). Cosmosophia: Cosmology, mysticism, and the birth of a new myth. Danvers Massachusetts: Hiraeth Press.

Romanyshyn, R. (2007). The wounded researcher: Research with soul in mind. New Orleans, Louisiana: Spring Journal Inc.

Wachs, B. (2011). Psychology needs poetry - part II. New Existentialist Posts, Saybrook University July 11, 2011. https://www.saybrook.edu/blog/2011/07/19/07-19-11/, accessed 31 August 2020.

Wallcott D. (1992). Nobel Lecture. December 7, 1992. https://www.nobelprize.org/prizes/literature/1992/ walcott/lecture/. Accessed 31 August 2020.

Publisher's Note Springer Nature remains neutral with regard to jurisdictional claims in published maps and institutional affiliations. 